\title{
Keeping Parents Involved Using 360-Class Monitoring Application
}

\author{
Siti Fatimah Abdul Razak, Basyirah Abdurahim, Faizuniza Mashhod \\ Faculty of Information Science and Technology, Multimedia University, Melaka, 75450, Malaysia \\ Email: fatimah.razak@mmu.edu.my, basyirah@live.com.my, faizuniza.mashhod@mmu.edu.my
}

\begin{abstract}
Parents play a vital role contributing towards student achievement. They need to be actively involved in organising and monitoring student time, assisting with homework and discussing school matters. Hence, 360Class Monitoring application aims to foster better communication between teachers, students and parents. The application enables effective and prompt communication in terms of updating parents on students' school work and assignments as well as school activities. For example, the application provides a platform for a teacher to post assignments which require students' actions along with the submission date. New entries by teachers will trigger email notifications to alert parents. Students and parents are able to view the post once they logged into the system.
\end{abstract}

Index Terms-Education technology, communication, mobile applications, monitoring students

\section{INTRODUCTION}

Close and effective communication between teachers and parents has been proven to help students perform better in schools [1]. This type of communication can either be one-way or two-way or combination of both. In a one way communication, teachers usually use communication books, report cards, school newsletter or websites to inform parents about student activities or progress whereas parents are only information receivers. On the contrary, a two-way communication allows interactive dialogue or change of roles between teachers and parents which eventually allows interactive feedback or responses from parents to teachers and vice versa. Combination of both one way and two way communication is most ideal to ensure close and effective communication between both parties [2].

Nevertheless, students are often the one expected to be the intermediaries responsible to receive and deliver any messages or information between teachers and parents [3] The ability of a student to share and convey messages to parents rely on the student abilities which differ from one student to another. In certain cases, some student especially those in primary schools may not be able to understand or misinterpret verbal messages by their teachers. As a result, miscommunication may happen between the three parties, i.e. teachers, students and parents.
To address this issue, common implementation is by issuing a circular or notice from the school or teachers to the parents [4]. This approach has been practised for so many years and is still being practised to support communication efforts between parents, students and teachers. However, the approach is less effective since students may forget, misplace or loose the paper prior to actually delivering it to their parents. Furthermore, the circular or notes may be accidently torn, ripped off or even exposed to rainy weather which may cause it to be unreadable.

Recent advancement in information technology has enabled schools and teachers to share information and communicate with parents in a timelier manner. Dependencies on student to pass the information between both parties are alleviated by integrating technology [3]. Official school websites, social media group and emails may help teachers communicate with parents faster. However, the success and effectiveness depends on parents' access to the said platforms. Furthermore, these platforms are generally used to share information on school events and activities in general and on ad-hoc basis only.

Apart from that, parents nowadays are torn between career and responsibilities towards their children. Their busy work schedule may cause them to be ineffective in planning a proper schedule [5]. Most of the time, parents are not aware or well-informed about their children's activities in school. As a result, this group of parents may face difficulties in monitoring and keeping track of their children's daily school activities. Given the opportunity, they prefer to be involved and promptly informed of their child's well-being and progress. This includes being aware of their child's activities in school, homework or tasks assigned by teachers, updates on schedule tests and exams as well as their child's need. As such, conventional method of communication may not be sufficient. Thus, other means of communication is deemed necessary to provide timely information and monitor the performance of a student.

This study aims to provide an alternative for teachers and parents to communicate as well as alleviating the task as intermediaries from the students. An application known as the 360-class monitoring application was developed to improve communication between teachers, parents and students especially for monitoring task or homework assigned to students. The application is 
accessible via smartphones $24 / 7$ and each entry by the teachers will trigger email notification to alert the parents.

This paper is organized in the following structure. Section I provides a brief overview of communication between teachers, parents and students. Section II described and compared similar technology-based and mobile applications which support communication between teachers, parents and students. Section III described the 360-Class Monitoring Application features. The testing procedures are described in Section IV whereas the last section, i.e. Section V concludes the paper by discussing future improvements and suggestions for the application.

\section{RELATED WORK}

Technology creates opportunities to directly link home and school. In other words, technology may foster effective communication between teachers and parents as well as transform the role and status of homework which eventually extends learning opportunities [6]. In addition, technologies which are flexible, accessible and provide interactive resources may facilitate and support parents engagement in their child's learning process [7].

In this study, several technology-based approach and similar existing systems developed to support communications between teachers, students and parents are investigated and summarised in the following subsections.

\section{A. School Portal}

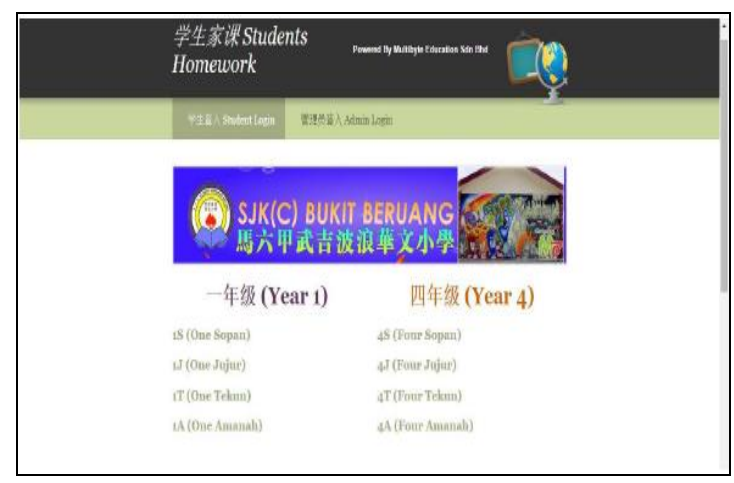

Fig. 1. Example of school portal for homework

School portal is a web portal for parents to monitor their children's activities and performance in school. For example, $\operatorname{SJK}(\mathrm{C})$ Bukit Beruang developed a school portal which enables teachers to list homework or assignments to be completed by students based on specific classes. Students and parents may log into the portal using pre-assigned unique ID to view the list (Fig. 1). A page admin is appointed to maintain the page. However, teachers need to request the page admin to update an entry on their behalves.

\section{B. Social media}

Nowadays, social media site like 'Facebook' is one of the must-use or preferred communication tools across the grid. Its interactive content and user friendliness allows lively and prompt interaction. For example, Sekolah Kebangsaan Kuala Kubu Bharu Dua created a facebook page as a platform to communicate with parents (Fig. 2).

Facebook pages are either created for the whole school or class groups. Group discussions are also set-up to allow parents to interact with teachers and school administrators directly. Parents may also refer to the page for updates on school activities. Apart from that, some Facebook groups or pages also allow teachers to post announcement regarding homework and assignments. In general, social media can support no-cost, fast and efficient information delivery to parents. However, security measures need to be enforced to avoid unlawful act of imposters posing as one of the parents to gain confidential information related to the students for the purpose of criminal intentions.

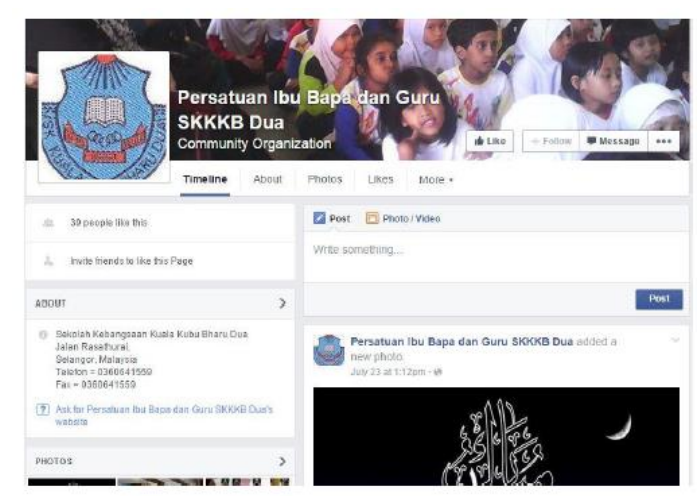

Fig.2. Example of facebook page for teachers-parents communication

\section{Mobile applications}

\section{Class Dojo (App. A)}

Class Dojo is developed to enable the teacher to track student's behaviour and provide instant and positive encouragement. Students are allowed to create their own account and view their personal achievement and progress throughout the class. Teachers and parents are engaged through an instant messaging platform which is capable of broadcasting reminders and allow private chats (Fig. 3(a)). This application is unique in terms of motivating students to participate in class activities. Students are rewarded by allowing them to customise personal avatar every time they achieved a specified milestones or show positive behaviours.
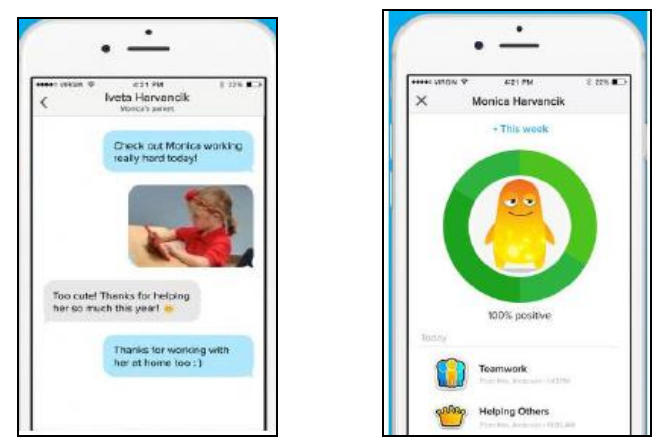

Fig.3(a) Class Dojo messenger (b) Class Dojo progress Tracker 
Even though the features are very appealing, the application does not provide remarks on the due date of tasks or assigned homework. In addition, teachers may have to broadcast from time to time, in order to remind parents to look into the homework or task given to their children. The size of the application is huge since it is enriched with animation and interactive interface. This may hinder parents from downloading and using the application.

\section{Rushyl Homework Application (App. B)}

This application aims to enable class homework postings via mobile phones. It also aims to provide early notification for parents so that parents may schedule the time for their children to work on the tasks and thus allow them to effectively monitor their children's work.

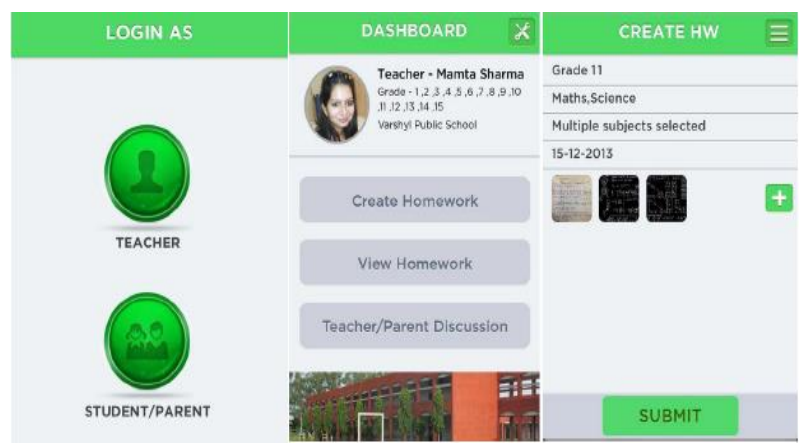

Fig.4(a). Main pages of the application

In order to post homework, teachers need to take a picture of the instructions for the homework which they have written on the board. Then, they need to select the grade and subject, add optional description and select due date for the homework. Once they press Submit button, the homework will be uploaded in the application (Fig. 4(a)).

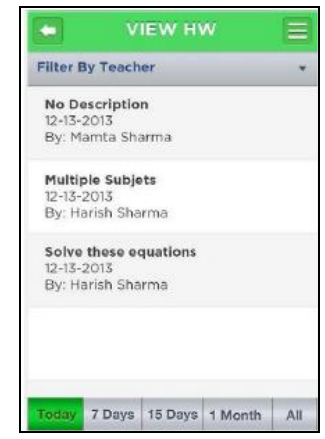

Fig.4(b). Student view

Students need to $\log$ in to the application and select their grade to view homework posted for the day. The homework may be filtered based on teachers, by week or by month (Fig. 4(b)).

The application lacks in terms of providing specific instruction related to the homework given and is highly dependent on teachers' smartphones to capture the images. The images may be blur or not clearly visible which may cause confusion. Notifications on homework due dates as well as parents notification are not available.
Teacher app. and grade book application (App. C)

The goal of this application is to inform and increase parental involvement related to student education thus increase the student motivation, test scores, and individual school performance. Many interesting features are available which includes grade book, school messenger system, class, student, parent messaging, interactive class calendar, events, course grades, assignment graders, assignment notes, send assignments, attendance records instant back-up, task/checklist, instant grade sharing, parent absentee notices, class structure, cloud account recovery, forgot password recovery, and group codes for school district.
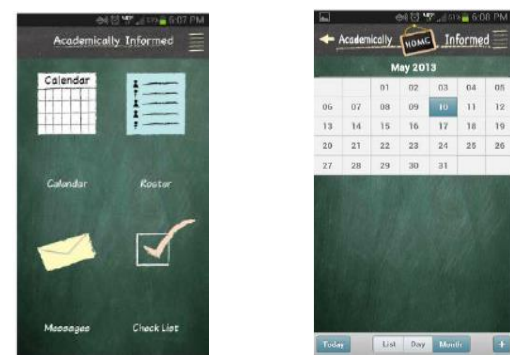

Fig.5(a). Teachers main page 5(b). Class calenda

Teachers are able to send important messages to parents, students and other teachers in a matter of seconds. Teachers are also able to add events to the class calendar for parents and students information. Besides that, teachers are able to add attachments, grades, student notes, and student attendance records to keep parents and students informed (Fig. 5(a) adn Fig. 5(b)).

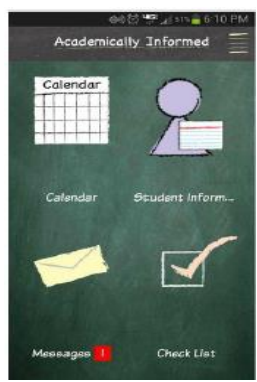

Fig.5(c). Parents main page

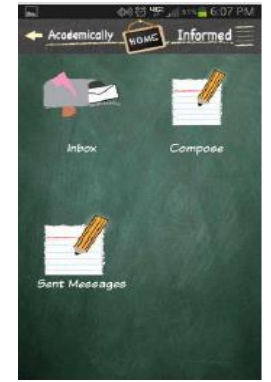

Fig. 5(d). Messaging features
Parents may access sent messages (Fig. 5(d)), grades, notes and attendance records based on input data from the teachers (Fig. 5(c)). Parents have the opportunity to message teachers, view the class calendar, and also send password protected absence notes straight through the application. Furthermore, students are allowed to view their grades, send messages, and access their attendance records. Students will be aware of their progress, which will require them to accept ownership for their individual reports.

The downside of this application is that parents and students are required to purchase an account in order to register and use this application. However, a fourteen days trial is available prior to actual purchase. The application has high complexity due to many features included even though the main focus is on student's 
grades and attendance records. The interactive calendar is applied to post about school events only

\section{Comparisons}

The reviewed mobile applications are compared and summarised based on application features or modules for teachers, parents and students role in Table 1.

Table 1. Comparisons between App. A, B and C.

\begin{tabular}{|l|l|l|l|}
\hline Modules & \multicolumn{1}{|c|}{ App A } & \multicolumn{1}{c|}{ App B } & \multicolumn{1}{c|}{ App C } \\
\hline Teacher & $\begin{array}{l}\text { Give awards } \\
\text { and } \\
\text { achievement } \\
\text { marks to } \\
\text { student based } \\
\text { on their } \\
\text { participation. }\end{array}$ & $\begin{array}{l}\text { Able to add } \\
\text { homework and } \\
\text { attach a picture } \\
\text { related to the } \\
\text { homework. }\end{array}$ & $\begin{array}{l}\text { Display } \\
\text { assignment } \\
\text { grades, record } \\
\text { attendance, and } \\
\text { upload student } \\
\text { notes }\end{array}$ \\
\hline Parent & $\begin{array}{l}\text { Able to view } \\
\text { student's } \\
\text { achievement in } \\
\text { class, receive } \\
\text { broadcast } \\
\text { messages from } \\
\text { teachers and } \\
\text { chat personally } \\
\text { with teachers. }\end{array}$ & $\begin{array}{l}\text { Able to view } \\
\text { student's } \\
\text { homework } \\
\text { pictures added } \\
\text { by teachers. }\end{array}$ & $\begin{array}{l}\text { Able to view } \\
\text { student's class } \\
\text { grades, } \\
\text { checklist and } \\
\text { event calendar } \\
\text { as well as chat } \\
\text { personally with } \\
\text { teachers. }\end{array}$ \\
\hline $\begin{array}{l}\text { Customize } \\
\text { personal avatar } \\
\text { and view } \\
\text { personal } \\
\text { achievement in } \\
\text { class. }\end{array}$ & $\begin{array}{l}\text { Able to view } \\
\text { students } \\
\text { homework } \\
\text { picture added } \\
\text { by teachers. }\end{array}$ & $\begin{array}{l}\text { Allow to view } \\
\text { student's } \\
\text { grades, } \\
\text { checklist and } \\
\text { event on the } \\
\text { class calendar. }\end{array}$ \\
\hline
\end{tabular}

\section{360-CLASS MONITORING APPLICATION}

In this study, a mobile application known as the 360Class Monitoring application was developed with the aim to provide an effective communication tool between teachers, students and parents. This application intends to support information sharing related to students' homework or assignments as well as related information about upcoming lessons.

\section{A. System Requirements}

This application was developed using Java programming language, Android Studio, Java Development Kit (JDK), GenyMotion Emulator and SQLite as well as Structured Query Language (SQL).

- Android studio

An Integrated Development Environment (IDE) for application development for android. The IDE consist an Android SDK tool and Android Virtual Device (AVD) Manager which enables debugging process.

- Java Development Kit (JDK)

A tool use to compile, debug, run Java programming language (Java-based) applets and application.

- SQLite

An open sources database which supports standard relational database features like SQL syntax, transaction and prepared statement as well as acts as library or storage for all project-related data.
- Java

An object-oriented programming language suitable for developing small-scale applications.

- $\quad$ Structured Query Language (SQL)

Used to communicate with SQLite database and perform tasks such as data updates or retrieval.

B. System Architecture

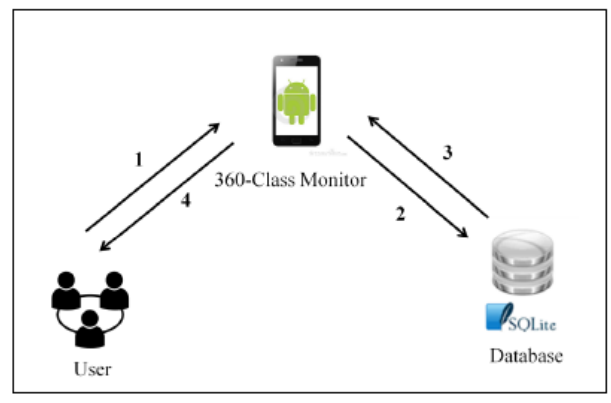

Fig.6. System architecture

Fig. 6 illustrates the system works in general. First, user needs to key-in required data inside the application (1). Second, user input data are stored in the SQLite database (2). Third, once the application is launched, the relevant data are retrieved from the database (3). Data are displayed upon request by authenticated and authorised user (4).

\section{System Interface and Features}

A menu-based navigation approach was applied for flexible and easy navigation. Teachers are able to create, edit, and post homework descriptions for parents and students to view. Apparently, parents and students view are similar since these two parties share a similar objectives, i.e. to get details of homework or assignment posted by teachers. However, parents have an additional feature which is receiving alerts and email notifications of new posts [8]. Aside from that, this application also will be included with a calendar features. The homework and information of future lessons are presented in a calendar form in order for these three users to get a clear view on the homework's due date.

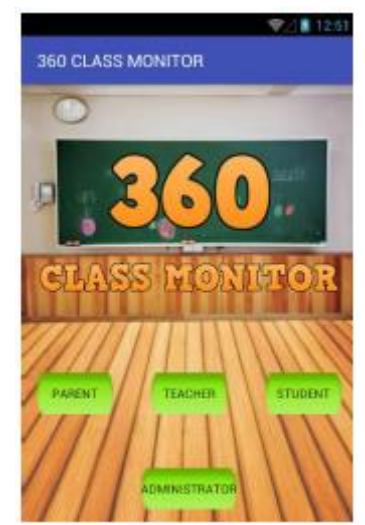

Fig.7. Main menu

Fig. 7 illustrates the main page of the 360-Class Monitoring application with four user options, i.e. parent, 
teacher, student and administtration. Administration refers to school administrator to provide master data for parents, teachers and students. Adminstrators need to log into to the system to manage the master data. The login page is shown in Fig. 7(a). Fig. 7(b) is displayed upon successful login. The applications allow three attempts to login, after which the application will automatically if the credential provided are still incorrect.
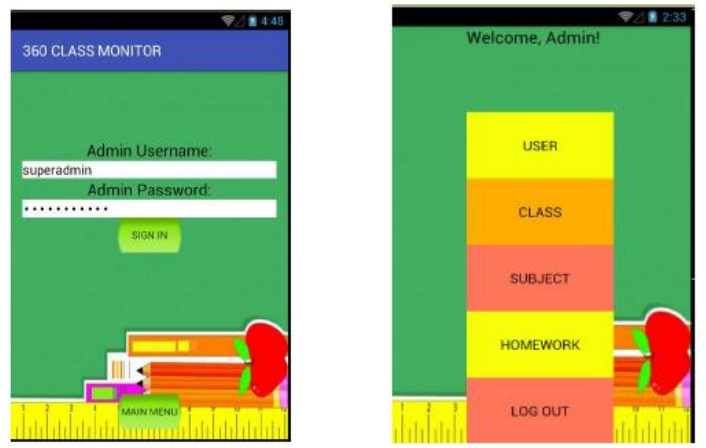

Fig.7(a). Admin log-in page (b). Admin main menu

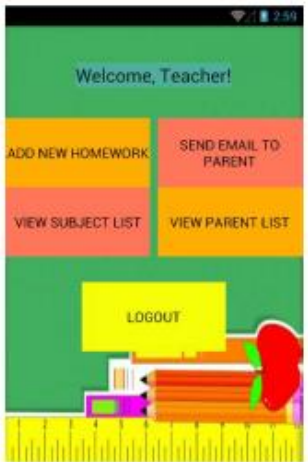

Fig.8. Teachers menu

In addition, upon successful log-in, teachers are able to add a new homework, send email notification to parents and view subject or parents list (Fig. 8). To add a new homework, the teacher must first choose a class. For example, class 1 Cerdik. Then, the teacher must add descriptions of the homework including subject, date assigned, submission date and details of the tasks (Fig. 8(a). Once submitted, the title of the homework appears in a calendar list view (Fig. 8(b)).

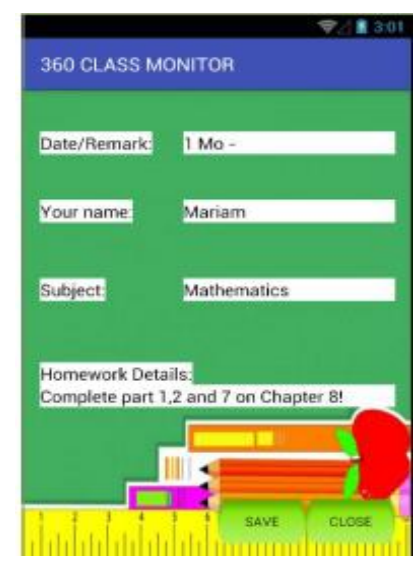

Fig.8(a). Add homework/task details

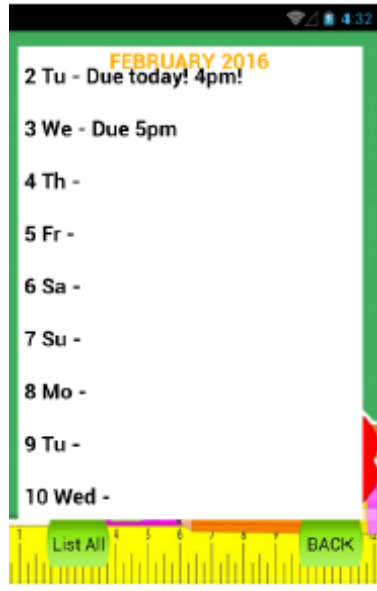

Fig.8(b). Calendar list view

Teachers can either email a specific parent of his students or send email notifications to parents of the whole affected class. In this case, email notification regarding the new added homework/task will be sent to all parents of 1 Cerdik. Teachers are not limited to post on homeworks or task only. They can also post other matters related to upcoming lessons like items to bring, tests or quizzes to be conducted and etc. Specific email may also be sent to specific parent to inform the parent of certain issues pertaining to a specific student or child.

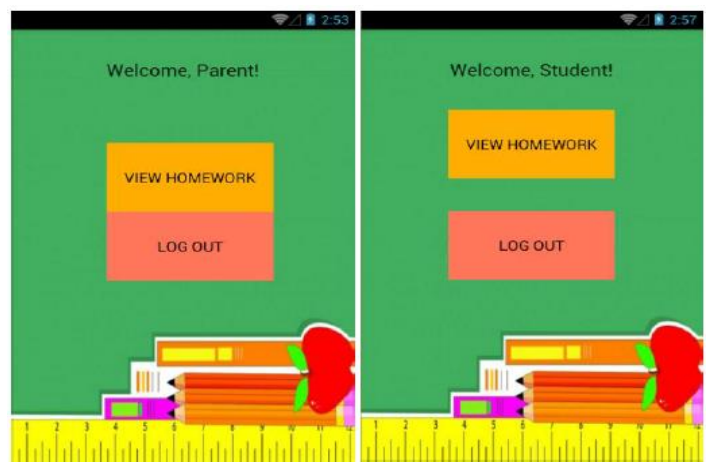

Fig.9. Parents and students view

Furthermore, parents and students share the same view (Fig. 9). Both parties may only view the homework or task posted by respective teachers for the student's class. They may view by selecting the month and filtering by date to get details of the homework or posted information.

All parties may log-out from the application at anytime they wish by pressing the Logout button.

\section{TESTING}

During the development phase, functionality testing was performed to ensure that the application is able to produce the expected outcomes consistently and accurately. Results indicates that the application is performing as expected and free from error or bugs. Summary of the test is tabled in Table 2. 
Table 2 . Summary of functionality testing

\begin{tabular}{|c|c|c|}
\hline Features & Expected Outcome & $\begin{array}{l}\text { Actual Result } \\
\text { (Pass/Fail) }\end{array}$ \\
\hline \multicolumn{3}{|c|}{ A. $\quad$ Login/Logout activity (Admin/Teacher/Parent/Student) } \\
\hline $\begin{array}{l}\text { Insert username and } \\
\text { password in the } \\
\text { given textfield. }\end{array}$ & $\begin{array}{l}\text { Usernmame and Password } \\
\text { match; User is directed to } \\
\text { Admin Main Menu }\end{array}$ & Pass \\
\hline $\begin{array}{l}\text { Click on Logout } \\
\text { button }\end{array}$ & $\begin{array}{l}\text { Successfully navigate to } \\
\text { Main Page }\end{array}$ & Pass \\
\hline \multicolumn{3}{|c|}{ B. Admin - App. User Data Entry } \\
\hline $\begin{array}{l}\text { Enter Teacher / } \\
\text { Parent/ Student } \\
\text { details }\end{array}$ & $\begin{array}{l}\text { Successfully store input } \\
\text { data }\end{array}$ & Pass \\
\hline $\begin{array}{l}\text { View Teacher/ } \\
\text { Parent/ Student List }\end{array}$ & $\begin{array}{l}\text { Successfully list all } \\
\text { required details }\end{array}$ & Pass \\
\hline $\begin{array}{l}\text { Edit Teacher/ } \\
\text { Parent/ Student List }\end{array}$ & $\begin{array}{l}\text { Successfully updates/ } \\
\text { overwrite existing data }\end{array}$ & Pass \\
\hline \multicolumn{3}{|c|}{ C. Admin Activity - Add class and subject } \\
\hline $\begin{array}{l}\text { Add Class and } \\
\text { Subject }\end{array}$ & $\begin{array}{l}\text { Successfully store in the } \\
\text { database }\end{array}$ & Pass \\
\hline $\begin{array}{l}\text { View Class and } \\
\text { Subject List }\end{array}$ & $\begin{array}{l}\text { Successfully list out all } \\
\text { the class and subject } \\
\text { details }\end{array}$ & Pass \\
\hline $\begin{array}{l}\text { Edit Class and } \\
\text { Subject }\end{array}$ & $\begin{array}{l}\text { Successfully overwrites } \\
\text { the previous data. }\end{array}$ & Pass \\
\hline \multicolumn{3}{|c|}{ D. Teacher - Send Email To Parent } \\
\hline $\begin{array}{l}\text { Add parent's email } \\
\text { address in the text } \\
\text { field. }\end{array}$ & $\begin{array}{l}\text { Successfully store in the } \\
\text { database }\end{array}$ & Pass \\
\hline $\begin{array}{l}\text { Select existing } \\
\text { email address }\end{array}$ & $\begin{array}{l}\text { Selected email address is } \\
\text { visible in the email text } \\
\text { field }\end{array}$ & Pass \\
\hline $\begin{array}{l}\text { Click on Send } \\
\text { button }\end{array}$ & $\begin{array}{l}\text { Successfully sends the } \\
\text { message to the desired } \\
\text { email address. }\end{array}$ & Pass \\
\hline $\begin{array}{l}\text { Click on Back } \\
\text { button }\end{array}$ & $\begin{array}{l}\text { Successfully direct to } \\
\text { Teacher Main Menu. }\end{array}$ & Pass \\
\hline \multicolumn{3}{|c|}{ E. $\quad$ Teacher - View Subject and Parent List } \\
\hline $\begin{array}{l}\text { Click on Subject } \\
\text { and Parent List } \\
\text { button }\end{array}$ & $\begin{array}{l}\text { Successfully display list } \\
\text { of subjects and parents }\end{array}$ & Pass \\
\hline $\begin{array}{l}\text { Select specific } \\
\text { parent }\end{array}$ & $\begin{array}{l}\text { Successfully display the } \\
\text { details and email address } \\
\text { of the parent }\end{array}$ & Pass \\
\hline \multicolumn{3}{|c|}{ F. $\quad$ Parent/ Student - View Homework } \\
\hline Select month & $\begin{array}{l}\text { Successfully display } \\
\text { homework list in the } \\
\text { calendar list view format }\end{array}$ & Pass \\
\hline Select date & $\begin{array}{l}\text { Successfully display the } \\
\text { homework details }\end{array}$ & Pass \\
\hline
\end{tabular}

Once the application has passed the functionality test, compatibility and usability of the application on multiple devices are assessed. This test is important since there are numerous types of mobile devices with vast software and hardware requirements [9]. Hence, the application was tested using a virtual device on the Genymotion Emulator.

Table 3. List of tested devices

\begin{tabular}{|l|l|}
\hline \multicolumn{1}{|c|}{ Virtual device } & \multicolumn{1}{c|}{ Android version } \\
\hline Google Nexus 4 & 4.1 .1 - API 16 \\
\hline Samsung Galaxy S3 & 4.1 .1 - API 16 \\
\hline HTC Evo & 4.2 .2 - API 17 \\
\hline
\end{tabular}

This emulator displays all kind of devices that supports android platform. There were three virtual devices that were chosen to test out this application as listed in Table
3. In conclusion, the application works best using Google Nexus 4 with android version 4.1.1 API 16. Hence, we assume that the appication will work well on other devices with similar android version.

\section{CONCLUSIONS AND FUTURE WORK}

360-Class Monitoring application is an application aimed to support effective communication process between teacher, parents, and students. The main objective is to provide a communication tool which enable teachers to post information regarding homework or tasks for students and parents. Both parents and students will be able to keep track of the homework's due date using a calendar list view. In addition, parents are notified via email to alert them about the new homework.

Literature search was conducted on different teacherparent technology based communication tools including three similar mobile applications. The three mobile applications were compared based on its functions.

The 360-Class Monitoriung applications can be further improved. For example, a standard calendar view can be applied to represents the dateline of each homework. A simple marks or highlights on the date can be the right element to keep track of the homework's due date. Features can be enhanced by adding personal chats platform to support personal chats between teachers and parents, thus to keep up to date with the children activities in school.

Instead of using email notifications, this application can be improve by using SMS (Short Messaging Service) to notify parents about newly added homework or task for their children. Teachers should also be made aware of the number of submissions required for a specific day. This allows teachers to re-consider their homework or task submission date should they found that students already have many tasks required to be submitted on the same day.

\section{REFERENCES}

[1] University of Illunois Extension. "Helping Children Succeed in School," n.d. [Online]. Available: http://extension.illinois.edu/succeed/communication.cfm [Accessed: 23-July-2015].

[2] Clay, S. G. "Communicating with Parents: Strategies for Teachers," [Online]. Available: www.adi.org/journal/ss05/Graham-Clay.pdf [Accessed: 23-July-2015].

[3] Ramirez, F. "Technology and Parent Involvement", Clearing House: A Journal of Educational Strategies, Issues and Ideas, 75(1), 2001, 30-31. [Online]. Available: DOI:10.1080/00098650109599230 [Accessed: 15-March2016].

[4] Lys, D. "Parental involvement : From Communication and Conference," [Online]. Available: https://www.ecu.edu/cseduc/opd/upload/Parental_Involvement.pdf [Accessed: 23July-2015].

[5] McCann, J. "No Time for the Family? You are Not Alone: Parents and Children Spend Less Than an Hour with Each Other Everyday because of Modern Demands," 2013, July 14. [Online]. Available: http://www.dailymail.co.uk/ 
article- 2363193/No-time-family-You- Parents-childrenspend-hour-day-modern- demands.html [Accessed: 23July-2015].

[6] Lewin, C. and Luckin, R. "Technology to Support Parental Engagement in Elementary Education: Lessons Learned from the UK", 2010, Computers \& Education 54 (3) pp. 749-758 [Accessed: 23-July-2015].

[7] Harris, A. and Goodall, J. "Do Parents Know They Matter? Engaging All Parents in Learning", 2008, Educational Research, 50 (3) pp. 277-289 [Online]. Available: DOI: 10.1080/00131880802309424 [Accessed: 23-July-2015]

[8] Thompson, B. " The Role of Email in Parent-Teacher Communication", 2008 [Online]. Available: https://www.natcom.org/CommCurrentsArticle.aspx?id=8 [Accessed: 23-July-2015]

[9] Flora, Harleen K., Xiaofeng Wang, and Swati V. Chande. "An Investigation into Mobile Application Development Processes: Challenges and Best Practices." International Journal of Modern Education and Computer Science 6.6 (2014): 1 [Online]. Available: http://www.mecspress.org/ijmecs/ijmecs-v6-n6/IJMECS-V6-N6-1.pdf [Accessed: 17-March-2016].

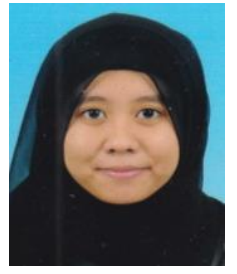

Basyirah Abdurahim is a final year student in B. IT (Hons Information Technology Management programme in Multimedia University. Her current research interest is in system development, android application and tutoring systems.

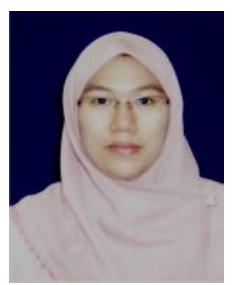

Faizuniza Mashhod is currently a lecturer in Faculty of Information Science and Technology, Multimedia University. She received her B. Sc. (Hons) in Information Technology from University Utara Malaysia and Master of Computer Science (Software Engineering and Intelligence) from University Teknikal Malaysia Melaka. Her primary research interest includes Web designing, information system development and educational technology.

\section{Authors' Profiles}

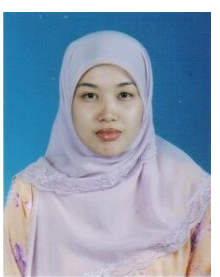

Siti Fatimah Abdul Razak received her B.Sc (Hons) with education where she majors in Mathematics and Information Technology and Master of Information Technology majoring in Science and System Management from the National University of Malaysia in 2004. She is currently a staff in Faculty of Information Science and Technology, Multimedia University. Her research interest includes rule mining, information systems development and educational technology.

How to cite this paper: Siti Fatimah Abdul Razak, Basyirah Abdurahim, Faizuniza Mashhod,"Keeping Parents Involved Using 360-Class Monitoring Application", International Journal of Modern Education and Computer Science(IJMECS), Vol.8, No.12, pp.10-16, 2016.DOI: 10.5815/ijmecs.2016.12.02 